\title{
RANCANGAN APLIKASI PEMBELIAN DAN PENJUALAN KOMPUTER PADA JAYASAKTI COMPUTER BERBASIS DESKTOP
}

\author{
Bhaktiar Roni Prasetyo ${ }^{1}$, Puji Astuti², Noni Selvia ${ }^{3}$ \\ 1,2,3 Jurusan Teknik Informatika,Fakultas Ilmu Komputer, Universitas Indraprasta PGRI Jakarta \\ Jalan Raya Tengah No 80, Kelurahan Gedong, Pasar Rebo, Jakarta Timur \\ ${ }^{1}$ bhaktiar.roni11@gmail.com, ${ }^{2}$ poetie12@gmail.com, ${ }^{3}$ noni.selvia@gmail.com
}

\begin{abstract}
ABSTRAK
Permasalahan yang terdapat pada Jayasakti Computer adalah proses pembelian dan transaksi penjualan masih manual dengan menggunakan buku besar dalam setiap pencatatan nya, sehingga sering terjadi kesalahankesalahan yang akan menyebabkan kerugian bagi Jayasakti Computer dan pembuatan laporan kepada pemilik toko masih membutuhkan banyak waktu sehingga tidak efisien. Tujuan merancang suatu sistem informasi pembelian dan penjualan ini dengan tujuan untuk memudahkan admin dalam memproses pengolahan data yang ada saat ini. Perangkat aplikasi yang telah dibuat dengan bahasa pemrograman Java NetBeans 8.0.2 dan penyimpanan data pada database MySQL dapat memberikan kelancaran dalam proses menginput dan penyimpanan data-data serta laporan-laporan yang diberikan kepada pemilik toko. Dengan menggunakan metode pengembangan sistem yaitu Waterfall dalam penelitian ini adalah dengan tahapan-tahapan seperti rekayasa sistem, analisis, desain, coding, testing, dan maintenance. Hasil dari penelitian ini menciptakan suatu sistem informasi pembelian dan penjualan dapat memudahkan pihak toko dalam proses pendataan data barang, data pembelian barang, data penjualan serta data return pembelian yang lebih baik dan akurat. Selain itu, tingkat efektivitas keberhasilan aplikasi ini cukup tinggi dilihat dari kepuasan pelanggan dengan proses transaksi yang baik dan cepat.
\end{abstract}

Kata Kunci: Aplikasi, Pembelian, Penjualan, Desktop

\begin{abstract}
The problem found in the Jayasakti Computer is that the process of buying and selling sales transactions is still manual by using a ledger in each of its records, so mistakes often occur that will cause losses for the Jayasakti Computer and making reports to store owners still takes a lot of time. so inefficient. The purpose of designing a buying and selling information system is to make it easier for admins to process the current data processing. Applications that have been made with the Java NetBeans 8.0.2 programming language and data storage in the MYSQL database can provide smooth processing of input and storage of data and reports provided to shop owners. By using the system development method, namely Waterfall, in this research, the stages are systems engineering, analysis, design, coding, testing, and maintenance. The results of this study create a purchasing and sales information system that can facilitate the store in the process of collecting data on goods, purchase data, sales data and purchase return data that is better and more accurate. In addition, the level of effectiveness of the success of this application is quite high seen from customer satisfaction with a good and fast transaction process.
\end{abstract}

Key Word: Application, Purchase, Selling, Desktop

\section{PENDAHULUAN}

Salah satunya penerapan teknologi komputer sebagai alat bantu yang mutlak dipergunakan sebagai pendukung utama dalam persaingan bisnis dan dukungan sumber daya manusia yang baik. Untuk dapat menciptakan dan menghadapi kondisi yang demikian, perlu adanya sistem informasi yang dapat melayani segala macam aspek informasi yang menyangkut kemampuan, kecakapan, keahlian, pengalaman dan potensi karyawan secara cepat, tepat, dan akurat yang selanjutnya dapat digunakan dalam penetapan kebijaksanaan atau keputusan serta pelaksanaan dalam pengolahan data serta sistem informasi pembelian dan penjualan komputer di Jayasakti Computer agar bisa berkembang (Ali, 2019).

Jayasakti Computer merupakan toko yang profesional yang bergerak dibidang elektronik dengan didukung oleh tenaga ahli berpendidikan yang kredibel. Tetapi ada permasalahan didalam pendataan proses pembelian dan penjualan karena semua nya dikerjakan secara manual tidak adanya suatu 
sistem informasi sebagai penunjang proses tersebut (Sholikhah, Sairan, \& Syamsiah, 2017).

Permasalahan yang paling signifikan adalah pada proses penginputan data, proses pembelian barang ke supplier dan transaksi penjualan serta laporan ini masih dilakukan secara manual, sehingga data yang didapat seringkali bermasalah karena kesalahan dari manusia, misalnya ketika bagian administrasi membutuhkan informasi mengenai stok barang masuk dan barang keluar maka harus dilakukan pengecekan ke gudang dan melakukan pengontrolan barang. Pelaporan data penjualan sering sekali terlambat pada saat penyerahan laporan bulanan kepada pemilik toko (Sari, 2017).

Perancangan sistem informasi yang akan diterapkan dapat memudahkan dalam pengolahan data sehingga mendapatkan manfaat yaitu membantu pengolahan data secara terkomputerisasi untuk memudahkan dan mempercepat proses transaksi, memudahkan pencarian data, memudahkan pembuatan laporan dan meminimalisir kesalahan proses jual beli (Abdurahman, 2017).

Dengan permasalahan tersebut, perlu ada nya suatu sistem yang terkomputerisasi dalam penyelesaiannya. Sistem adalah sekelompok unsur yang erat hubungannya satu dengan yang lain, yang berfungsi bersama-sama untuk mencapai tujuan (Sutabri, 2012). Sistem merupakan suatu kumpulan dari komponenkomponen yang membentuk satu kesatuan (Tyoso, 2016). Pembangunan sistem adalah sekumpulan aktivitas yang menggambarkan secara rinci bagaimana sistem akan berjalan. Hal itu bertujuan untuk menghasilkan produk perangkat lunak yang sesuai dengan kebutuhan user (Satzinger, J. W., Jackson, R. B., Burd, n.d.).

Diharapkan dengan adanya suatu sistem informasi dapat menangani permasalahan yang ada di perusahaan tersebut. Sistem adalah setiap sesuatu terdiri dari obyek-obyek, atau unsur-unsur, atau komponen-komponen yang bertata kaitan dan bertata hubungan satu sama lain, sedemikian rupa sehingga unsur-unsur tersebut merupakan satu kesatuan pemrosesan atau pengolahan yang tertentu. (Prasojo, 2011)
Adapun penelitian yang terdahulu dengan peneliti (Gultom \& Maryam, 2020) dengan hasil penelitian Sistem Informasi Penjualan Material Bangunan (Studi Kasus: Toko Bangunan Berkah) dibuat untuk membantu pelaksanaan sistem transaksi penjualan yang terjadi di Toko Bangunan Berkah, yang sebelumnya masih dilakukan secara manual. Maka dengan adanya sistem ini dapat mempermudah pekerjaan transaksi penjualan dan pengelolaan stok barang masuk menjadi lebih efektif dan efisien. Sistem ini juga dapat melakukan cetak laporan laba yang berguna untuk mengetahui keuntungan bersih dari penjualan sesuai rentang tanggal yang dipilih.

Dari hasil penelitian sebelumnya makan aplikasi yang dirancang oleh penulis memiliki pembaharuan yaitu ada nya laporan penjualan yang real-time kemudian ada nya laporan return pembelian kepada supplier apabila ada barang yang rusak. Sehingga dengan ada nya pembaharuan aplikasi ini maka dapat memudahkan pekerjaan Admin dalam melaksanakan proses penginputan data, pencarian data serta pembuatan laporan.

\section{METODE PENELITIAN}

Peneliti menggunakan metode Research and Development dalam penyelesaian penelitian ini. (Sugiyono, 2016). Dalam pelaksanaan $\mathrm{R} \& \mathrm{D}$, ada beberapa metode yang digunakan yaitu metode deskriptif, evaluatif dan eksperimental. Metode penelitian deskriptif digunakan dalam penelitian awal untuk menghimpun data tentang kondisi yang ada yaitu penulis membutuhkan data-data yang dapat menunjang tercipta nya suatu sistem informasi penjualan seperti data barang, data pelanggan, data pembelian data penjualan dan data return pembelian terdahulu yang masih tersimpan secara manual didalam buku besar. Metode evaluatif digunakan untuk mengevaluasi proses ujicoba pengembangan suatu produk, dalam proses ini penulis melakukan ujicoba terhadap suatu sistem yang telah dirancang agar tidak ada terjadi kesalahan dalam proses penginputan data serta pelaporan bulanan kepada pemilik toko. Dan metode eksperimen digunakan untuk menguji keampuhan dari produk yang dihasilkan, dalam 
proses yang terakhir ini perlu dilakukan pengujian akhir yang diharapkan bahwa sistem yang dirancang oleh penulis dapat berjalan dengan baik dan sesuai dengan kebutuhan dan terfokus pada proses pembelian dan penjualan komputer pada Jayasakti Computer (Putra, 2011).

Adapun desain penelitian pada metode Research and Development sebagai berikut.

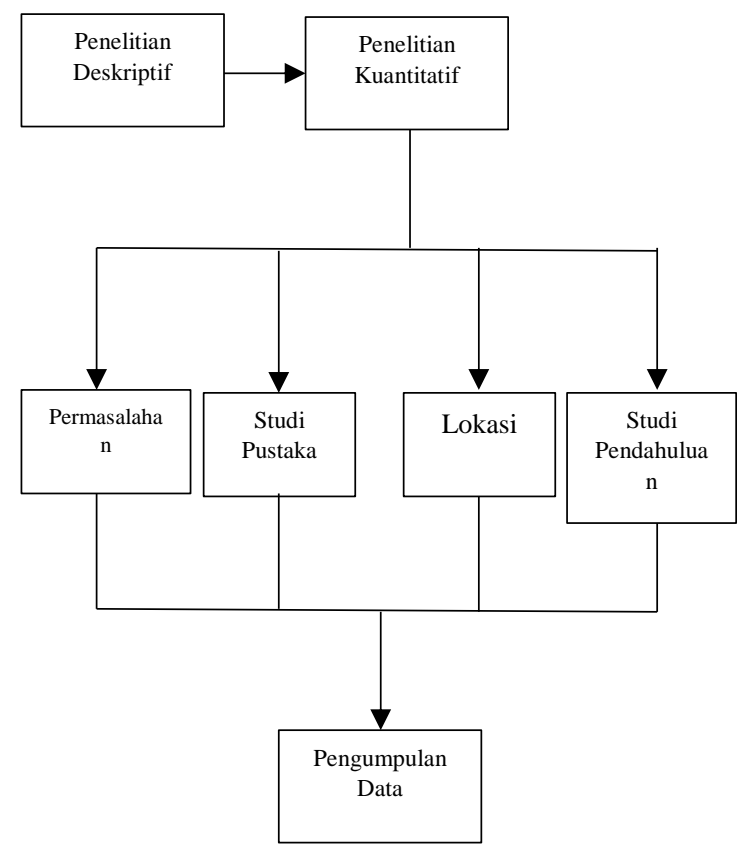

Gambar 1. Desain Penelitian

\section{HASIL DAN PEMBAHASAN}

\section{Analisa Permasalahan}

Dari pembahasan diatas penulis mengambil simpulan atas permasalahan yang ada diantaranya:

1. Penulisan data masih dilakukan secara manual dalam pencatatan data pembelian dan penjualan maupun dalam pembuatan laporan.

2. Proses pencatatan secara manual memerlukan tempat penyimpanan yang sangat luas, akibat kertas yang bertumpuk serta memerlukan waktu yang lama dalam proses pencarian kembali data.

3. Pelayanan terhadap pelanggan menjadi tidak efisien dan mungkin akan terjadi kesalahan akibat waktu yang lama dalam pencarian data.

\section{Alternatif Penyelesaian Masalah}

Berdasarkan analisis sistem yang sedang berjalan saat ini penulis melihat kelemahankelemahan dan pokok permasalahan yang terdapat pada sistem pembelian dan penjualan pada Toko Jayasakti Computer, maka penulis dapat menyarankan beberapa alternatif permasalahan yang dapat dicoba, yaitu:

1. Agar tidak terjadi keterlambatan didalam proses pengerjaan informasi, sebaiknya dikoordinasi dengan baik dan terkomputerisasi dengan benar antara sub sistem yang satu dengan yang lainnya, dan sebaiknya Jayasakti Computer membuat rancangan sistem yang dapat meringankan dalam bertransaksi, membuat laporan, mengecek data-data khususnya pada penjualan.

2. File atapun data yang sudah dikerjakan sebaiknya disimpan ke Harddisk ataupun alat penyimpanan data yang lain, dan jika perlu dibuat backupnya jika saat teradi kesalahan memiliki cadangan file ataupun data-data.

3. Alangkah baiknya bila komputer yang digunakan untuk memproses data di upgrade, sehingga pemrosesan data tersebut dapat dilakukan lebih baik, cepat dan tepat.

Dirancangnya suatu sistem informasi pembelian dan penjualan komputer pada Jayasakti Computer yang terkomputerisasi ini, diharapkan dapat mempermudahkan proses pengerjaan dan pengecekan data khususnya pada proses pembuatan laporan dan transaksi penjualan.

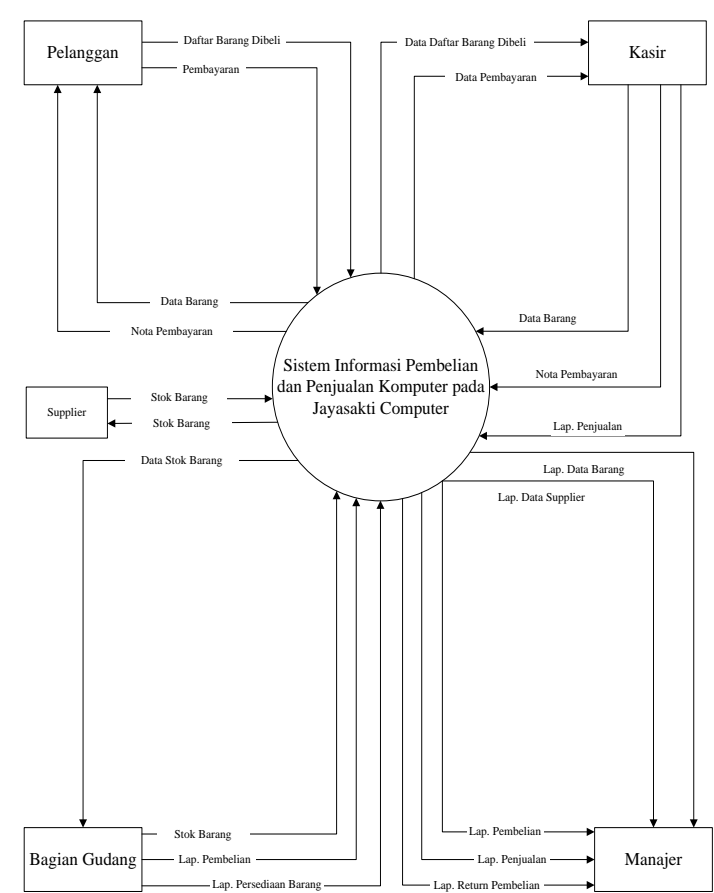

Gambar 2. Diagram Konteks 


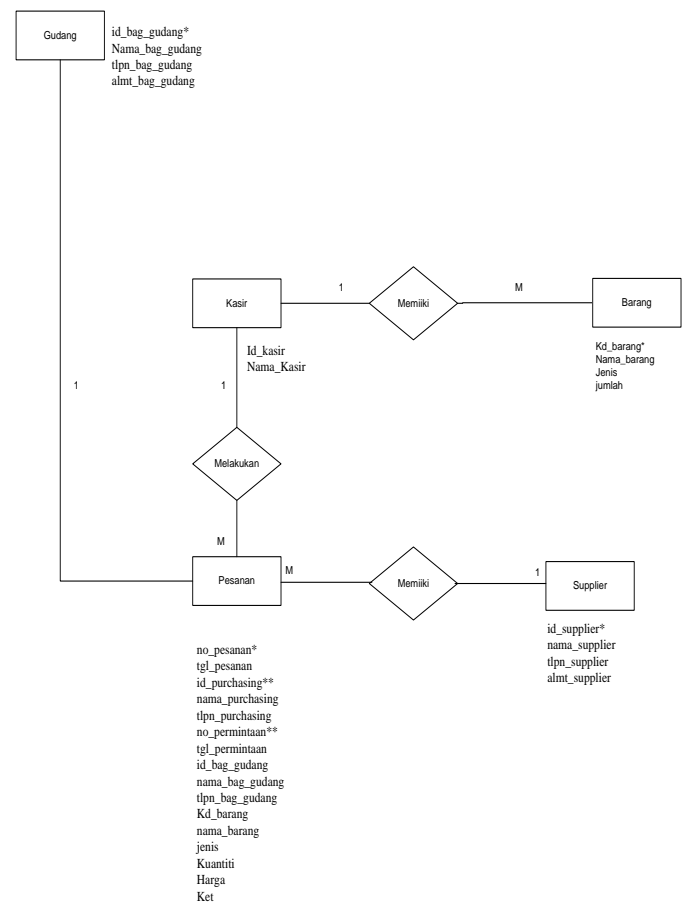

Gambar 3. Entity Relationship Diagram

Berikut adalah tampilan layar dan hasil pengujian pada software program yang telah di buat dengan bahasa pemrograman Java.

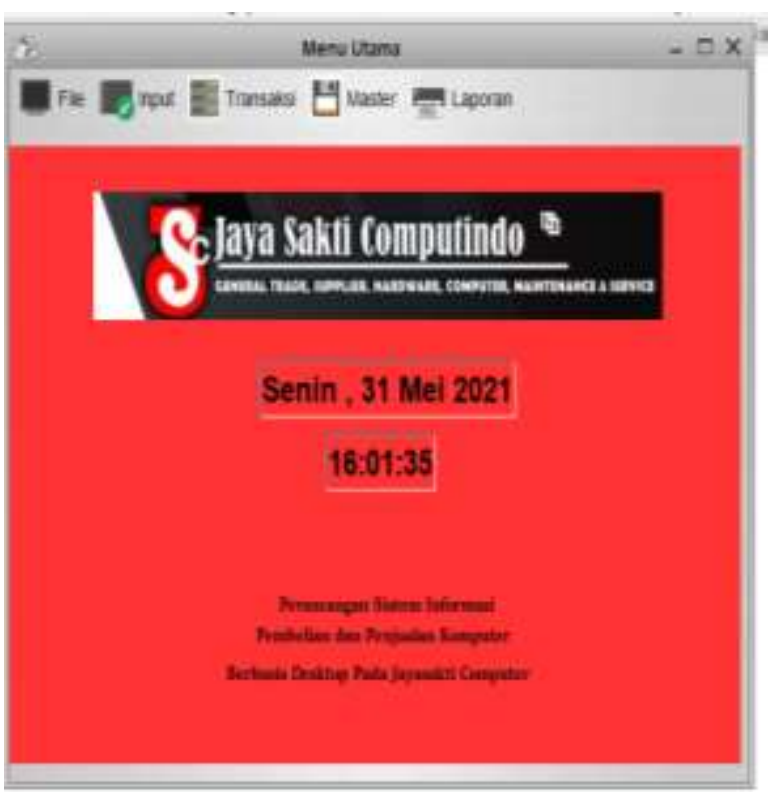

Gambar 4. Form Menu Utama

Layar di atas menampilkan tampilan Menu Utama pada Aplikasi Pembelian dan Penjualan Komputer pada Jayasakti Computer. Pada layar utama tersedia menu bar yang terdiri dari master data yang digunakan untuk memasukkan data yang berkaitan dengan data jenis barang, data barang, data supplier, data pembelian, data penjualan, data return pembelian, dan laporan-laporan.

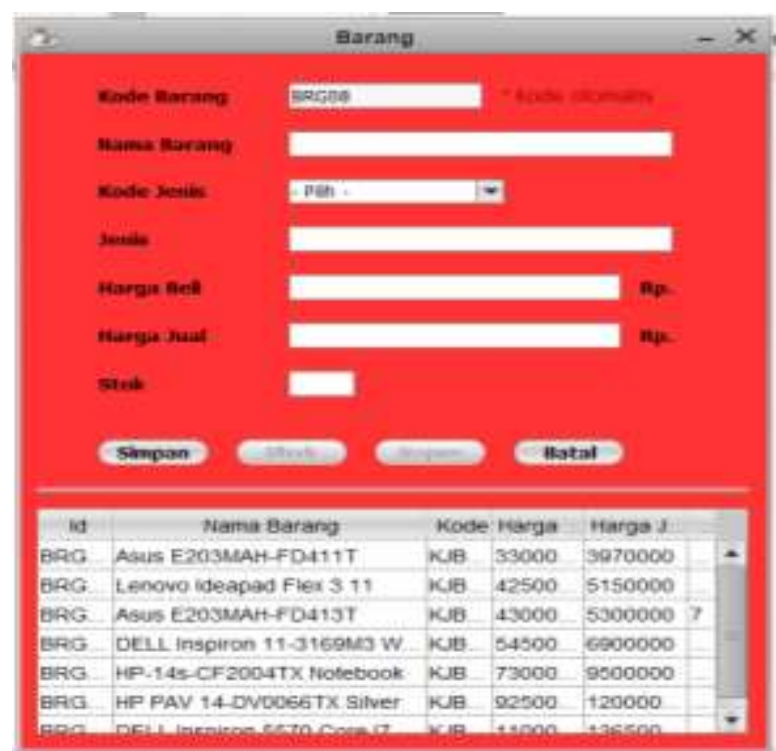

Gambar 5. Form Data Barang

Layar di atas menampilkan tampilan form data barang. Pada layar form data barang untuk meng-input data barang yang terdiri dari Kode Barang, Nama Barang, Kode Jenis, Jenis Barang, Harga Beli, Harga Jual dan Stok.

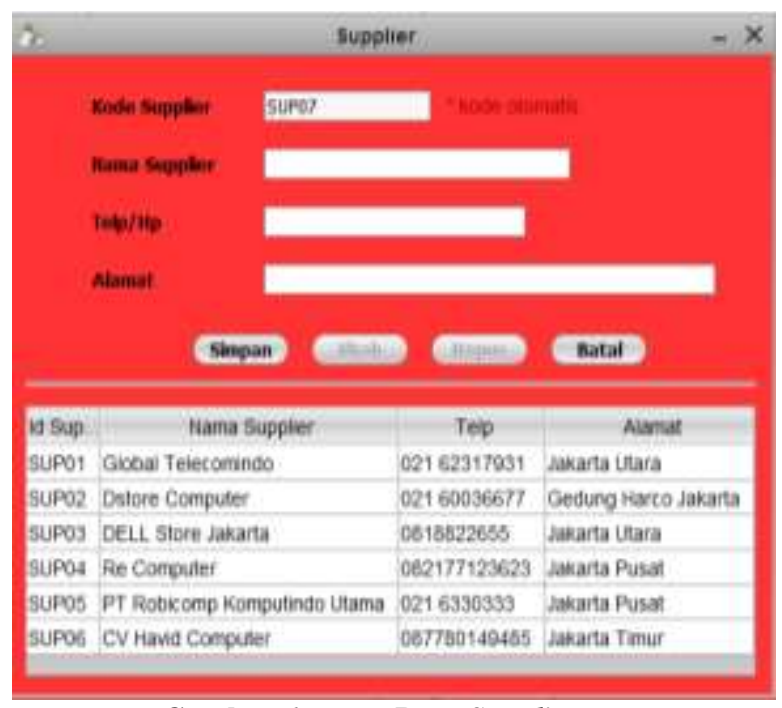

Gambar 6. Form Data Supplier

Layar di atas menampilkan tampilan form data supplier. Pada layar form data supplier untuk meng-input data supplier yang terdiri dari Kode Supplier, Nama Supplier, No Telp dan Alamat. 


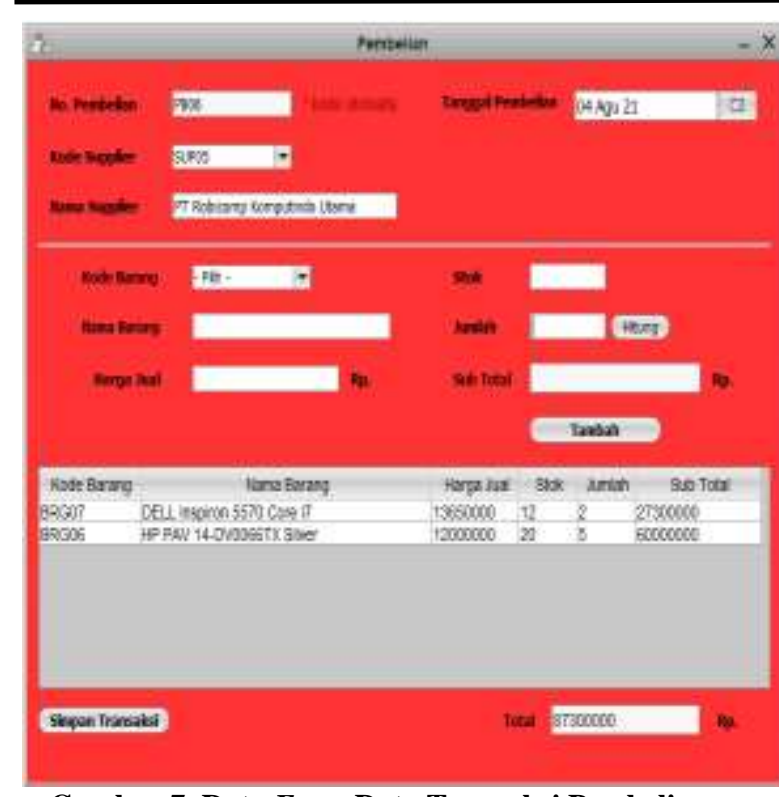

Gambar 7. Data Form Data Transaksi Pembelian

Layar di atas menampilkan tampilan form data transaksi pembelian. Pada layar form data transaksi pembelian untuk meng-input data transaksi pembelian yang terdiri dari No Pembelian, Tgl Pembelian, Kode Supplier, Nama Supplier, Kode Barang, Nama Barang, Harga Jual, Stok, Jumlah dan Sub Total.

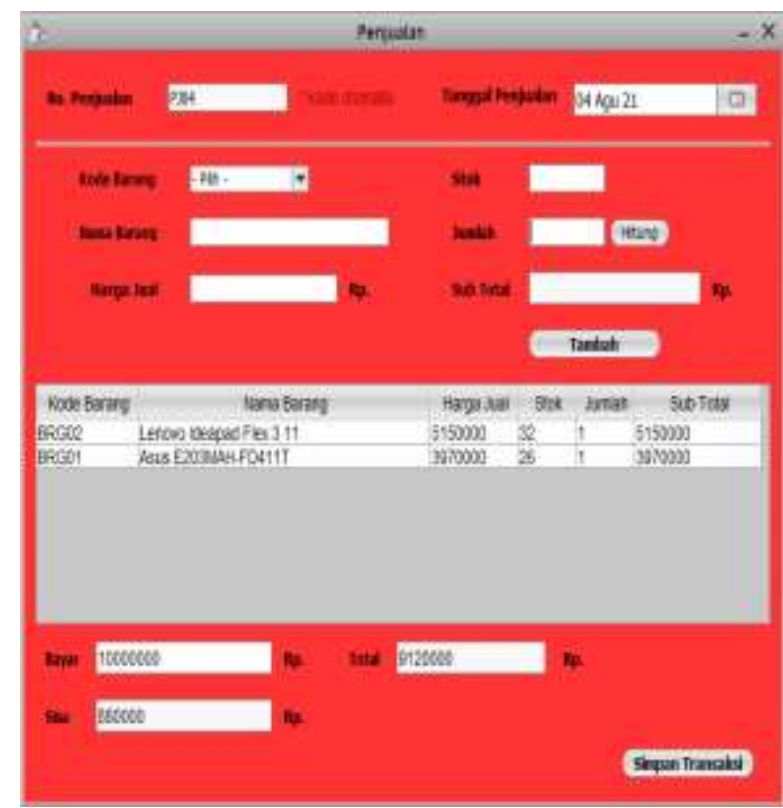

Gambar 8. Form Data Transaksi Penjualan

Layar di atas menampilkan tampilan form data transaksi penjualan. Pada layar form data transaksi penjualan untuk meng-input data transaksi penjualan yang terdiri dari No Penjualan, Tgl Penjualan, Kode Barang, Nama Barang, Harga Jual, Stok, Jumlah dan Sub Total.

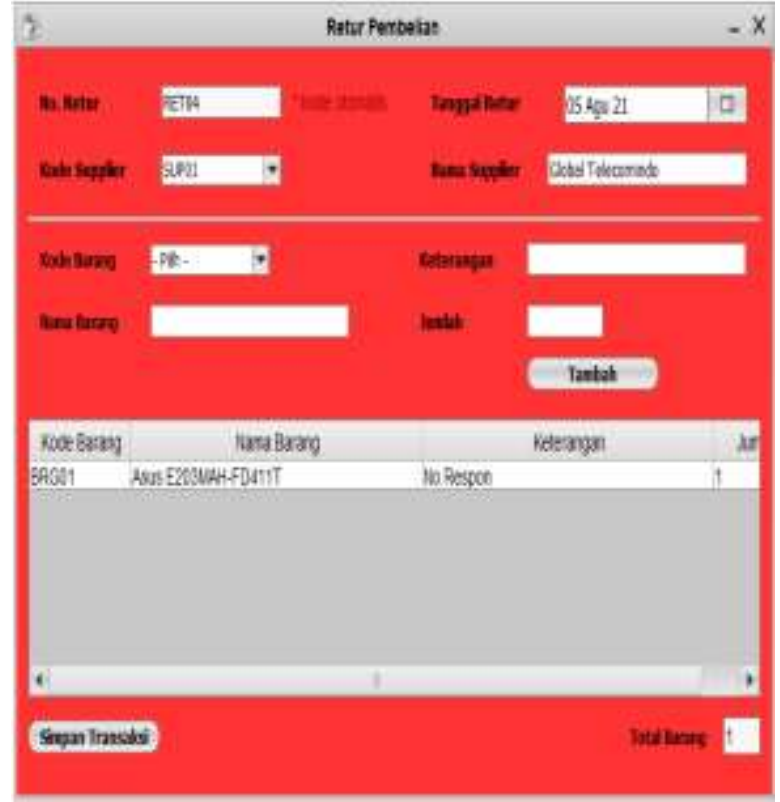

Gambar 9. Laporan Data Return Pembelian

Layar di atas menampilkan tampilan form data return pembelian. Pada layar form data return pembelian untuk meng-input data return pembelian yang terdiri dari No Retur, Kode Supplier, Nama Supplier, Tanggal Retur, Kode Barang, Nama Barang, Keterangan dan Jumlah.

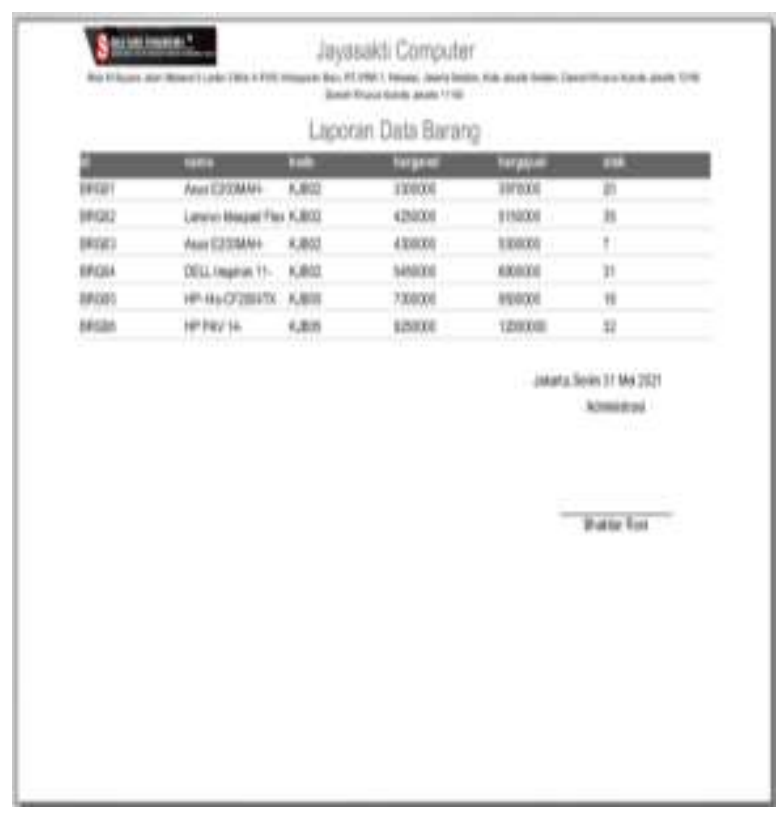

Gambar 10. Laporan Data Barang

Layar di atas menampilkan tampilan form laporan data barang. Pada layar form data barang digunakan untuk mengecek laporan data barang terdiri Kode Barang, Nama Barang, Kode Jenis, Jenis Barang, Harga Beli, Harga Jual dan Stok. 


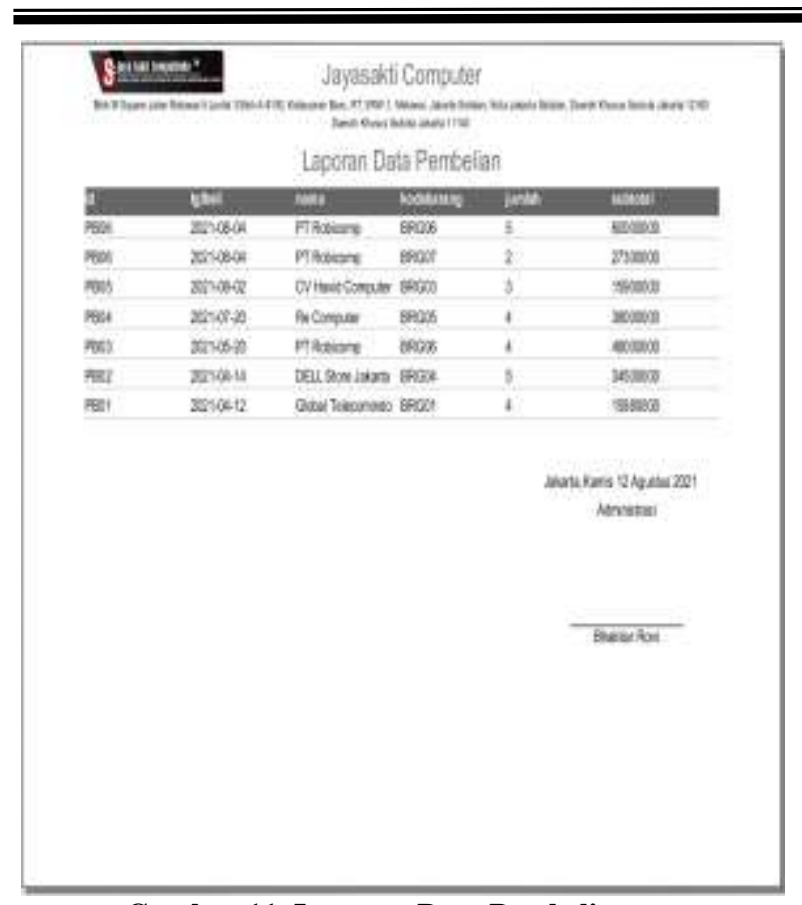

Gambar 11. Laporan Data Pembelian

Layar di atas menampilkan tampilan bukti pengembalian mobil. Pada layar bukti pengembalian mobil terdiri dari Kode Pengembalian, Tgl Kembali, ID Petugas, Nama Petugas, ID Booking, NIK, Nama Karyawan, Model dan Keterangan.

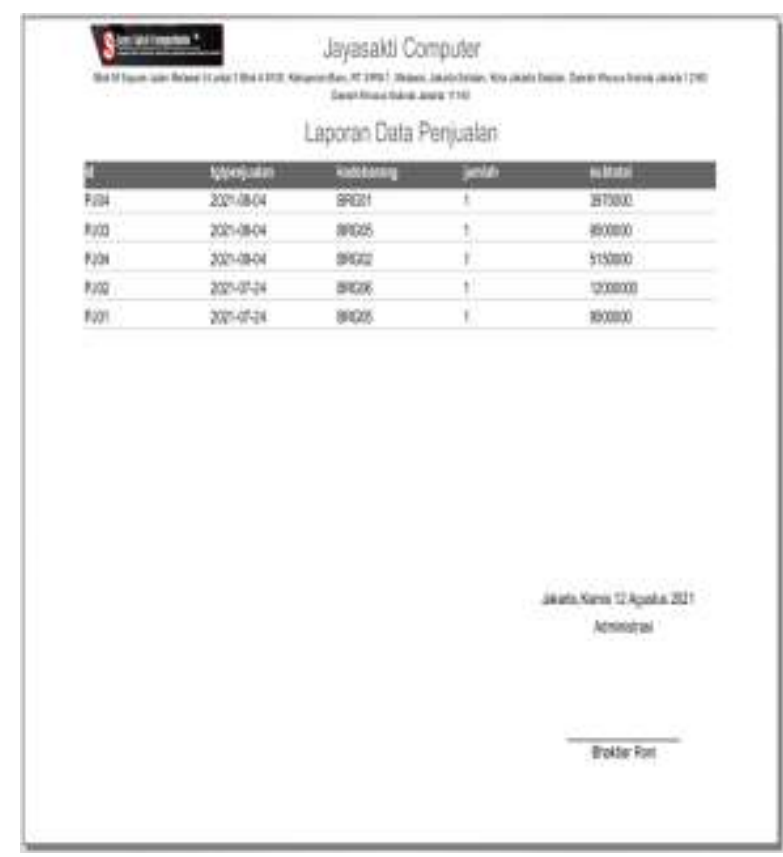

Gambar 12. Laporan Data Penjualan

Layar di atas menampilkan tampilan form laporan data penjualan. Pada layar form data penjualan digunakan untuk mengecek laporan data penjualan terdiri No Penjualan, Tgl Penjualan, Kode Barang, Jumlah dan Sub Total.

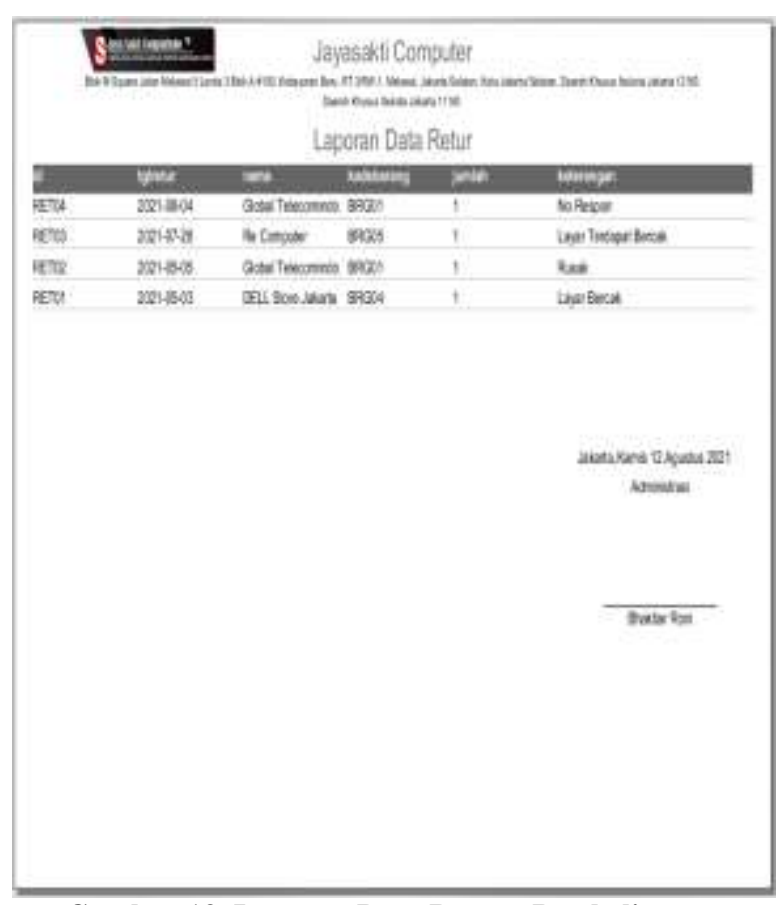

Gambar 13. Laporan Data Return Pembelian

Layar di atas menampilkan tampilan form laporan data retur pembelian. Pada layar form data retur pembelian digunakan untuk mengecek laporan data retur pembelian terdiri No Retur, Tanggal Retur, Nama Supplier, Kode Barang, Jumlah, Keterangan.

\section{SIMPULAN DAN SARAN}

Sistem aplikasi yang dirancang sudah layak digunakan untuk proses pembelian dan penjualan komputer pada Jayasakti Computer karena sudah sesuai dengan kebutuhan, sehingga dapat mempermudah admin dalam proses penginputan data serta pembuatan laporan. Sistem aplikasi pembelian dan penjualan komputer pada Jayasakti Computer untuk memudahkan admin dalam proses penginputan serta pencarian data seperti data barang, data supplier, data pembelian, data transaksi penjualan serta data return pembelian karena data yang sudah terinput akan tersimpan dengan baik didalam database. Selain itu, tingkat efektivitas keberhasilan aplikasi ini cukup tinggi dilihat dari kepuasan pelanggan dengan proses transaksi yang baik dan cepat.

Saran untuk peneliti selanjutnya adalah aplikasi penjualan ini sebaiknya untuk menggunakan metode SDLC dengan pengujian System Usability Scale (SUS) dalam menentukan penilaian. 


\section{DAFTAR PUSTAKA}

Abdurahman, M. (2017). Sistem Informasi Pengolahan Data Pembelian Dan Penjualan Pada Toko Koloncucu Ternate. IJIS Indonesian Journal On Information System. https://doi.org/10.36549/ijis.v2i1.22

Ali, A. F. (2019). Rancang Bangun Aplikasi Penjualan Barang Berbasis Java Programming. Simtika.

Gultom, M. M., \& Maryam. (2020). Sistem Informasi Penjualan Material Bangunan Pada Toko Bangunan Berkah Information System of Sales Building Material ( Case Study: Berkah Building Shop ). Jurnal Teknik Informatika (JUTIF), 1(2), 79-86.

Prasojo, M. (2011). Pengantar Sistem Informasi Manajemen. bandung: CV. Remadja Karya.

Putra, N. (2011). Research and Development, Penelitian dan Pengembangan: Suatu Pengantar. Jakarta: PT Raja Grafindo Persada.

Sari, Y. P. (2017). Rancang Bangun Aplikasi Penjualan Dan Persediaan Di Kota Prabumulih. Jurnal Sistem Informasi Dan Komputerisasi Akuntansi (JSK).

Satzinger, J. W., Jackson, R. B., Burd, S. D. (n.d.). System Analysis and Design in A Changing World. USA: Cengage Learning.

Sholikhah, I., Sairan, M., \& Syamsiah, N. O. (2017). Aplikasi Pembelian Dan Penjualan Barang Dagang Pada CV Gemilang Muliatama Cikarang. Teknik Komputer AMIK $B S I, I I I(1), 16-23$.

Sugiyono. (2016). Metode Penelitian Kuantitatif, Kualitatif dan $R \& D$. Bandung: PT Alfabet.

Sutabri, T. (2012). Analisis Sistem Informasi. Yogyakarta: Andi.

Tyoso, J. S. P. (2016). Sistem Informasi Manajemen. Yogyakarta: DeePublish. 